\title{
DETERMINANTS OF OUTBOUND MEDICAL TOURISM: IMPLICATIONS FOR SERVICE MARKETING AND DEVELOPMENT
}

\author{
Felix John EZE \\ University of Calabar, Department of Marketing, Nigeria, e-mail: ezefelixjohn@unical.edu.ng \\ Juliet John INYANG* \\ University of Calabar, Department of Marketing, Nigeria, e-mail: julijohn@unical.edu.ng \\ Nina Valentine ORJI \\ University of Calabar, Department of Marketing, Nigeria, e-mail: ninaorji26@gmail.com
}

\begin{abstract}
Citation: Eze, F.J., Inyang, J.J., \& ORJI, N.V. (2020). DETERMINANTS OF OUTBOUND MEDICAL TOURISM: IMPLICATIONS FOR SERVICE MARKETING AND DEVELOPMENT. GeoJournal of Tourism and Geosites, 33(4spl), 1507-1512. https://doi.org/10.30892/gtg.334spl09-600
\end{abstract}

\begin{abstract}
This study examined the demand factors responsible for outbound medical tourism to India, South-Africa and Germany. The demand factors included medical tourist attitude, medical destination competitiveness, medical service cost and medical service quality. Using snowball sampling, 138 medical tourists were surveyed with the aid of a self-administered 24-item 5-point scale questionnaire. The data obtained were analyzed using multiple regression analysis. The findings of the study were that tourist attitude has no significant influence on outbound medical tourism; Medical destination competitiveness significantly influences outbound medical tourism negatively; whereas, medical service cost and medical service quality significantly influence outbound medical tourism positively.
\end{abstract}

Key words: medical tourism, tourist attitude, destination competitiveness, service cost, service quality.

\section{INTRODUCTION}

Medical tourism is considered as a trip outside an individual's place of residence for the purpose of receiving medical treatment, diagnosis, or therapy; the tourists making use of the destination's infrastructure, attractions and facilities (Smith and Puczko, 2014). Over the years, people of developed and developing countries like Nigeria visit medical destination countries around the world for medical treatments dominant in cosmetic surgery treatment, weight loss treatment, dental treatment, fertility treatment, cardiovascular treatment, cancer treatment, orthopedic treatment and others. However, the most commonly and sought after treatments for patients in Nigeria, that make most outbound medical tours include treatment for cosmetic surgery, orthopedic treatment, cancer treatment as well as fertility treatment, which can't be satisfactorily rendered and received in their home country as a result of lengthy waiting time to get medical services in their home country, reduced service quality, high expenses and lack of medical insurance, or underinsurance (Ile and Ţigu, 2017).

In addition to the quality health services which Nigeria medical tourists seek, health tourism or medical tourism may include other facilities like better accommodation, shopping and sometimes recreational arrangements. The quest for better medical care has dramatically increased in recent times. This has consequently heightened the demand for medical tourism among most Nigerians. Abubakar et al. (2018) stated that $47 \%$ of Nigerians visiting India in the year 2012 did so to get medical attention, while the remaining $53 \%$ did so for other reasons. The $47 \%$ of Nigerians who visited India for medical purposes amounted to 18,000 persons and they expended $\$ 260$ million in scarce foreign exchange in the process. This trend signifies that there are potent reasons for embarking on medical tourism. According to Makinde (2016) thousands of Nigerians travel abroad each year to seek medical treatment mainly because the nation's health care system remains poorly funded. He also attributed the cause of medical tourism to poverty and lack of universal health coverage.

The practice of moving to other countries to receive high tech medical services are hinged on diverse range of motivators of which developing countries like Nigeria can take advantage of if it wants to achieve its goal of becoming a major medical tourism destination in Africa and the world at large. Thus it is essential to learn the factors that play the major role in consumer demand for medical tourism in order to succeed in this industry from the point of view of medical or health tourists.

Nigeria is undoubtedly one of the biggest sufferers from medical tourism in the world. Factors like inadequate medical equipment, inadequate service personnel, and also inadequate infrastructures (to mention a few) have greatly contributed to the abysmal state of Nigeria's healthcare sector, and this has in turn made people lose confidence in the sector. This lack of confidence in the healthcare sector has further led to the increase of Nigerians with life threatening ailments travelling abroad in search of better medical treatment and care. The demand factors are those factors in the health and economic environment that propel people with medical condition to seek remedies outside their countries. Factors such as: tourist attitude, destination competitiveness, service cost and service quality have been associated with the reasons why people with medical needs travel for remedies. In the case of Nigeria outbound tourism, the level of information on this subject is scanty. There is yet no agreement among practitioners and researchers on the demand factors that drive medical choice of destination.

It is in view of the aforementioned that the researcher is motivated to study the correlates between demand factors of Nigeria outbound medical tourists and their destination selection preferences. The specific objectives of this study are as follows:

1. To examine the effect of attitudes on Nigerian's propensity to participate in outbound medical tourism;

2. To explore the influence of medical destination competitiveness on the propensity of Nigerians to participate in outbound medical tourism;

3. To determine the effect of destination health service cost on the propensity to participate in outbound medical tourism; and

4. To investigate the effect of destination service quality on the propensity to participate in outbound medical tourism.

\section{LITERATURE REVIEW}

The study is based on the Means-End Chain theory and Abraham Maslow's hierarchy of needs theory. These theories form strong

\footnotetext{
${ }^{*}$ Corresponding author
} 
foundations to understanding tourist motives (Jiang et al., 2018). The Means-End Chain (MEC) theory posits that motivation can be studied to reveal the underlying reasons why certain attributes or expected consequences are desired. Means-End theory has been widely used in the marketing literature to identify values-based motivations behind consumption (Arsil et al., 2016). Means-End Chain theory is based on a model of consumers' cognitive structures, depicting the way in which concrete product characteristics are linked to valued end states desired by consumers. The theory focuses on the linkages among the attributes that exist in products (the means), the consequences for the consumer provided by the attributes, and the personal values (the ends) the consequences reinforce (Lin et al., 2018). The theory assumes that behavior is value-driven, whereby a consumer's personal values ultimately influence their product choices (Jeng and Yeh, 2016).

Means-End Chain theory is particularly useful for understanding personal values, and has relevant and potential application in tourism research to study tourist behavior (Jeng and Yeh, 2016). Application of the Means-End Chain theory in a tourism and leisure context has predominantly focused on understanding tourist behavior in terms of destination choice for medical tourism. The Means-End Chain is a useful method and theory that can be applied to understand the subtleties of tourists' behavior and salient dimensions in their thinking. This is important for recognizing the unique values and agendas that tourists bring with them into a tourism encounter and how these agendas may affect the nature of their resultant behavior or the experiences and satisfaction they gain (Jiang et al., 2018). The MEC theory is applicable to this study because medical tourists' behavior is value-driven, such that their personal values underpin by the following destination attributes (the need for a healthy living, self-esteem and individual prestige) ultimately influence their medical tourism destination choices.

Abraham Maslow's hierarchy of needs is a motivational theory in psychology comprising a five-tier model of human needs, often depicted as hierarchical levels within a pyramid. Needs lower down in the hierarchy must be satisfied before individuals can attend to needs higher up. From the bottom of the hierarchy upwards, the needs are: physiological, safety, love and belonging, esteem and selfactualization. Kapoor (2017) stated that people are motivated to achieve certain needs and that some needs take precedence over others. Our most basic need is for physical survival, and this will be the first thing that motivates our behavior.

Once that level is fulfilled the next level up is what motivates us, and so on. Maslow's hierarchy of needs theory is one of the fundamental theories that explain travel motives of tourists. For instance, the need for good health plays a major role in the travel decisions of individuals. This is tandem to the safety needs of Maslow's needs hierarchy (Setiawan, 2018). The social needs of Maslow's theory motivate the tourists to have holidays while away on medical tourism. Maslow's higher order needs such as social estee $\mathrm{m}$ and self-actualization fulfill the psychological aspects of the travelers. Tourists who engage in medical tourism have the tendency or urge to fulfill their social esteem needs by traveling abroad for medical purposes even when these treatments are available in their home country (Carvache-Franco et al., 2019). Hence, Maslow's hierarchy of needs theory helps to explain the intrinsic motivations of tourists; it also helps us understand medical tourists' attitude; and to unravel the actual motive for engaging in medical tourism.

\section{The medical tourism concept}

The World Tourism Organization in accordance with tourism segment classification identifies "medical treatment/health" as a major reason for travel and tourism. Medical tourism is an aspect of health tourism. It is often called medical travel because it includes the act of travelling to different countries for medical reasons (Ile and Țigu, 2017).

In general, medical tourism is considered as a trip outside a person's place of residence for the purpose of receiving a medical treatment, investigation or therapy, the tourists making use of destination's infrastructure, attractions and facilities (Smith and Puczko, 2014). There are various definitions of medical tourism, but the most recent definition by Fetscherin and Stephano (2016) implies that medical tourism is a form of health tourism, together with wellness tourism. The difference between the two forms of health tourism is in the fact that medical tourism implies existence of a medical distress, that needs to be investigated, diagnosed and treated by medical procedures, being considered a reactive form of a health tourism, while wellness tourism is a proactive one, implying preventing or maintaining health using alternative procedures, without implying specialized clinics, specialized medical personnel or invasive procedures (Fetscherin and Stephano 2016).

\section{Tourist attitude towards medical tourism}

In the tourism industry, customer or tourist attitude towards any destination is very important for its success. It may vary from person to person. This can be different on certain aspects like, customer group, age, gender, income, family structure, race, culture, social class and ethnicity. Food, clothes, politics and religion are crucial factors for human attitudes. Attitude can be defined as individuals' evaluation of feelings and tendencies toward an object or an idea. It is attitude which affects people to like or dislike something or to move towards or away from that (Jing, 2017). In medical tourism, Kuranchie-Mensah and Amponsah-Tawiah (2016) stated that the intrinsic motivation approach recognized that individuals have unique personal needs that stimulate or arouse them to pursue tourism (the desires to satisfy individual or internal needs - self-improvement, self-realization, or achieve state of happiness, and ego-enhancement). In contrast, the extrinsic motivation approach examines the broader conditioning factors that shape individuals' attitudes, preferences and perceptions, but are more externally determined (the society and the culture one lives in). Murayama (2018) suggested that the extrinsic and intrinsic motivation must be considered because travelers are variously motivated by intrinsic, self-satisfying goals and at other times are motivated by extrinsic socially controlled rewards (e.g. other's opinions). Hence, a change in tourist attitude can affect the medical destination choice.

\section{Destination competitiveness for medical tourism}

A desired destination of medical tourism should be a kind of product containing central rewards like commercial infrastructure and environmental factors. Comparative advantage of the destination may involve climate, surroundings, flora and fauna, while destination competing advantage may relate to attributes such as health and medical care areas, heritage/ historic attractions, events, transport sites, government policy, the actual quality of management and skills of workers (Al-Amin et al., 2011). The World Economic Forum defined the most aggressive location, as one that is liable to bring finest success; that arranges a surrounding which is the most suitable place for the residents for a certain schedule (Calderwood and Soshkin, 2019). Hence, competitiveness of a destination for medical tourism has to last besides, being simply affordable. In addition it should be socially, culturally, politically and environmentally sound and friendly. For that reason, it is always suggested that the most acceptable desired destination could be the one where medical tourists get a friendly environment. For example, India has achieved a desirable position in medical tourism because of its adaptability with the changing world demand for healthcare and its greater competitiveness (Datta, 2020). Singapore, Malaysia, Bulgaria and Cuba are also moving in this globalized industry very aggressively. However, it is not possible to highlight only one country as the greatest competitor in the field of medical tourism (Kiper, 2013).

\section{Service cost of medical tourism}

Consumers are very sensitive regarding the cost of any product or service. This is true for all types of customers especially price sensitive customers. Price of any product or service is a key element to determine the level of satisfaction of any customer (Hosseini, 2010). It should 
not exceed the expectation of customers. The competitiveness of any product or service largely depends on the total cost to obtain it. It may include, actual price of the product, transportation or installation cost, physical cost or hard work expended and social cost involved like getting appreciation or criticisms from others as well as opportunity costs to ignore other products (Crooks et al., 2011).

In the sector of tourism, a destination can be attractive to its tourists only when the costs of getting services are reasonable. There can be some exceptional cases but cost affect tourist choice and satisfaction. It involves certain types of expenditures like, accommodation cost, transportation cost, food cost, and other entertainment cost (Roy et al., 2017). Therefore, in medical tourism cost of medical service or fees, cost of accommodation, cost of food and transportation cost are vital issues for measuring the attractiveness of a destination.

\section{Service quality of medical tourism}

Medical tourists focus greatly on the service quality provided by the destination country. Thus the destination country must fulfill the expectations of the medical tourists through quality service and performance (Jiang, 2018). Quality improvement and its potentiality in travel and tourism services are very difficult to implement as it involves people from different countries with different cultural background and demands (Sultana et al., 2014). However, companies can improve service quality by lowering distribution costs and enhancing the service provided. In medical tourism if any country can provide quality healthcare services at low cost then it will definitely attract the world. In this sector meaning of quality service is a vast issue. It involves the quality of healthcare center as well as the doctors and other staffs (Sultana et al., 2014). However, healthcare is actually a very individual and critical service and it is not an easy task to define its quality.

Generally, service quality attributes outlined by (Pakurár et al., 2019) include tangibles, reliability, responsiveness, empathy and assurance. Service quality in medical tourism can be measured by the following five dimensions:

i. Tangibles-Appearance of physical medical, equipment, personnel, and communication materials;

ii. Reliability-Ability of medical personnel to perform the promised service dependably and accurately;

iii. Responsiveness-Willingness of medical personnel or facilitator to help medical tourists and provide prompt service;

iv. Assurance-Knowledge and courtesy of medical employees and their ability to convey trust and confidence;

v. Empathy-Caring, individualized attention the medical destination provides its tourists.

\section{Empirical Review}

Kim et al. (2019) conducted a research to analyze the factors that determine the motivation and behaviour of potential medical tourists on destination choice, with particular emphasis on the role played by destination image in the case of South Korea and Thailand. The study primarily collected data from an online survey of potential medical tourists, complemented with data from a hardcopy written survey. From the data analysis, the study found that individuals who are more inclined to undertake medical tourism are those who: (i) have an internal health locus of control; (ii) consider the cost of health-care services in their home countries to be financially unaffordable; and (iii) consider that the waiting time to receive desired treatment in their home countries is too long. The study also finds that there is a negative relationship between the information-search behavior of potential medical tourists and their familiarity with medical procedures and/or alternative destinations. In contrast, perceptions of risk, which might have been expected to have a positive effect on external information search, is not found to exert an influence in the study. Notably, the study also finds that prospective medical tourists are particularly motivated to consider four destination attributes in choosing a medical tourism destination: saving potential; quality of care; hygiene issues; and safety/security.

A research by Sultana et al. (2014) on the factors influencing the attractiveness of India as a health tourism destination found the major contributing factors and their relative importance in the attractiveness of the health tourism destination from consumers' perspectives by conducting survey with an application of structural equation modeling approach. The result revealed that in Indian context, medical tourists consider service quality and cost mostly in selecting any medical destination. In addition they also give value to the destination competitiveness but tourist attitude is less important in comparison with other factors affecting their destination choice. Their research concluded that in order to transform a country such as India into an attractive and competitive medical tourist destination in this time of globalization, a step should be taken to control cost ensuring the quality of services.

Lajevardi (2016) developed a theoretical structural model to examine the influence of motivational factor and perceived destination image on the perceived service quality and overall satisfaction of medical tourists. Factors studied included, destination image, quality, value, and satisfaction which occurred after the medical tourists have travelled to a foreign country to obtain a medical treatment. The study used 260 medical tourists who were surveyed via Qualtrics, an online survey research platform. After data collection was completed, Confirmatory Factor Analysis and SEM (Structural Equation Modeling) were used to analyze and interpret the result. The results show that destination image, motivational factor, perceived value and perceived quality positively influenced tourist overall satisfaction. Again, destination image had the strongest impact on perceived quality. Haarhoff and Mokoena (2017) carried out an exploratory study to investigate possible penetration into the South African medical travel market in order to advance expansion of the market by medical tourism facilitators (MTF). The study surveyed individuals who have made an appointment with a registered plastic surgeon. However, it was impossible to pre-determine the precise number of the population. A qualitative methodology was used to collect data anonymously from 236 voluntary respondents in the surgeon's waiting rooms after their consent was obtained. The results indicate that cosmetic tourists come from all over South Africa due to the attractive tourist packages offered by MTFs. The majority were females and they organized the leisure component themselves. Ile and Țigu (2017) studied scientific literature to find new medical tourism trends in connection with globalization and liberalization. They found that countries that decide to promote this niche tourism are aware of the huge economic benefits brought by this. Analyzing published secondary data by tourism medical organizations associated to indicators of economic development, they also found two interesting phenomenon; the success of a medical tourism destination is influenced by the economic growth level of the receiving countries, but, at the same time, it is also a growth factor for developing economies if it is included in their national strategy.

From far-reaching review of related literature, a conceptual framework of the study is presented in Figure 1. The conceptual model expresses the following four null hypotheses:

1. Tourists' attitudes have no significant effect on their propensity to participate in outbound medical tourism.

2. Medical destination competitiveness has no significant influence on the propensity to participate in outbound medical tourism.

3. Destination health service cost does not significantly affect the propensity to participate in outbound medical tourism.

4. Destination service quality does not significantly affect the propensity to participate in outbound medical tourism

\section{METHODOLOGY}

The study employed cross-sectional survey design. The population of the study comprised individuals who have expressed interest in medical tourism. This population is unknown, hence, the Topman Formula was used to arrive at a sample of 138 respondents using an error 
margin of 5\% (0.05). In selecting this sample snowballing sampling technique was employed as the sample elements were accessed through referrals from travel agents and medical practitioners/health care providers. The data for the execution of this study were mainly obtained from primary source through the use of a self-administered 24-item 5-point Likert scale questionnaire. Content-validation was used for the instrument validity, while Cronbach's Alpha coefficient was used to confirm the reliability after carrying out a pilot survey on 30 medical tourists in Calabar, in Southern Nigeria. This location was selected for the pilot study because Calabar is popularly known as the tourism hub of Nigeria. The Cronbach's alpha score for the five constructs are: Medical tourist attitude $=0.705$, Medical destination competitiveness $=$ 0.792 , Treatment service cost $=0.714$, Medical service quality $=0.853$ and Medical tourism participation $=0.744$. Data analysis technique employed was the multiple linear regression because it ascertains the causal relationship between the dependent (propensity to participate in medical tourism) and independent variables (medical tourist attitude, medical destination competitiveness, treatment service cost and medical service quality). This analysis was computed electronically with the aid of Statistical Package for Social Science version 23.

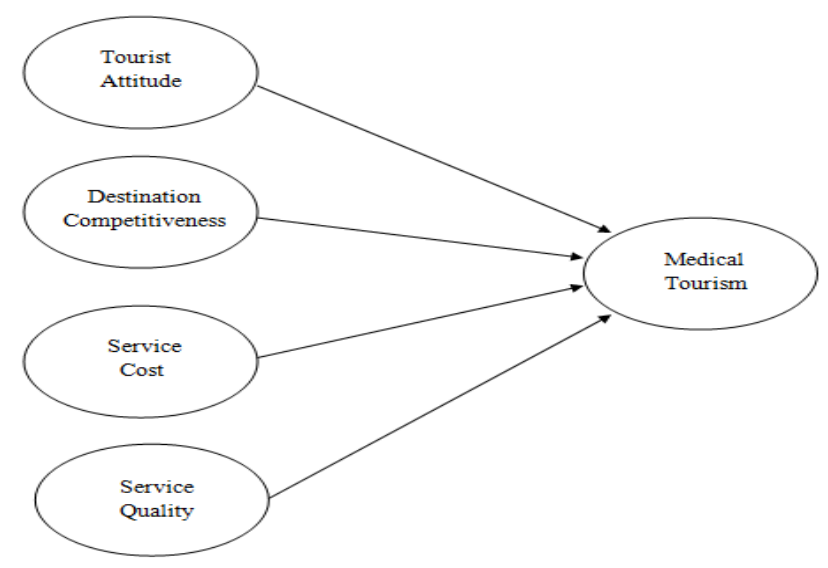

Figure 1. Conceptual model of factors influencing outbound medical tourism in Nigeria (Source: Adapted from Sultana et al., 2014)

\section{RESULTS AND DISCUSSION}

A total of 138 copies of questionnaire were distributed, 129 were completed and returned, while 9 copies of the questionnaire were not returned. The regression tables (Table 1, 2 and 3) show the demand factors (tourists' attitude, medical destination competitiveness, medical service cost, and medical service quality) being evaluated for its ability to influence outbound medical tourism by Nigerians. Table 1 which is the model summary reveals that the relationship between both variables is $44.4 \%$ (as seen in the $R$ column). The $R^{2}$ value $(0.197)$ signifies that up to $19.7 \%$ of outbound medical tourism is caused by the demand factors when other variables are held constant. This relationship is quite low, but significant. This indicates that the model has a low fit in estimating the population mean, that is, there are factors that are not added in this model. The F-test $(7.610, \mathrm{p}<0.05)$ of the relationship in Table 2 indicates that the overall prediction of the independent variable to the dependent variable is statistically significant, therefore, the regression model provides sufficient evidence to conclude that the demand factors significantly influence participation in outbound medical tourism. Table 3 is the coefficients table, which provides the necessary information on the capability of each demand factor to predict participation in outbound medical tourism. From the table it can be seen that not all the four variables (tourists' attitude, medical destination competitiveness, medical service cost, and medical service quality) significantly influence participation in outbound medical tourism. From the table it can be seen that medical tourist attitude has no significant influence on participation in outbound medical tourism ( $\mathrm{p}>0.05)$; medical destination competitiveness negatively affects participation in outbound medical tourism $(\mathrm{p}<0.05 ; \mathrm{t}=-2.007)$; medical service cost positively influence participation in outbound medical tourism $(\mathrm{p}<$ $0.05 ; \mathrm{t}=2.606)$; and medical service quality positively influence participation in outbound medical tourism $(\mathrm{p}<0.05 ; \mathrm{t}=4.672)$. Additionally, the standardized beta coefficient column in Table 3 shows the individual contributions of each of the variables to the model. It can be seen that with a beta coefficient of 0.592 (59.2 percent) medical service quality makes the highest and most positive contribution to the model. This is followed by medical destination competitiveness (with beta coefficient of 0.226). Next is medical service cost which contributes $22.3 \%$ to the model. The least contributing factor is the medical tourist attitude with a beta coefficient of 0.088 (that is 8.8 percent).

Table 1. Model summary of the effect of demand factors on Nigerians' participation in outbound medical tourism

\begin{tabular}{|c|c|c|c|c|}
\hline Model & $\mathrm{R}$ & $\mathrm{R}$ Square & Adjusted R Square & Std. Error of the Estimate \\
\hline 1 & $.444^{\mathrm{a}}$ & .197 & .171 & 1.786 \\
\hline a. Predictors: (Constant), SERVICE QUALITY, SERVICE COST, MEDICAL TOURIST ATTITUDE, DESTINATION COMPETITIVENESS \\
\hline
\end{tabular}

Table 2. Analysis of variance (ANOVA) on the effect of demand factors on Nigerians' participation in outbound medical tourism

\begin{tabular}{|l|c|c|c|c|c|c|}
\hline Model & Sum of Squares & Df & Mean Square & F & Sig. \\
\hline \multirow{4}{*}{1} & Regression & 97.138 & 4 & 24.285 & $.000^{\mathrm{b}}$ \\
\cline { 2 - 7 } & Residual & 395.699 & 124 & 3.191 & \\
\cline { 2 - 7 } & Total & 492.837 & 128 & & \\
\hline \multicolumn{2}{|l|}{ a. Dependent Variable: MEDICAL TOURIST PARTICIPATION } \\
\hline
\end{tabular}

Table 3. Coefficients for the effect of demand factors on Nigerians' participation in outbound medical tourism

\begin{tabular}{|c|c|c|c|c|c|c|}
\hline \multirow{2}{*}{\multicolumn{2}{|c|}{ Model }} & \multicolumn{2}{|c|}{ Unstandardized Coefficients } & \multirow{3}{*}{$\begin{array}{c}\text { Standardized Coefficients } \\
\text { Beta }\end{array}$} & \multirow{2}{*}{$\mathrm{T}$} & \multirow{2}{*}{ Sig. } \\
\hline & & B & Std. Error & & & \\
\hline \multirow{5}{*}{1} & (Constant) & 6.994 & 2.211 & & 3.163 & .002 \\
\hline & MEDICAL TOURIST ATTITUDE & -.088 & .096 & -.088 & -.922 & .358 \\
\hline & DESTINATION COMPETITIVENESS & -.242 & .121 & -.226 & -2.007 & .047 \\
\hline & SERVICE COST & .156 & .060 & .223 & 2.606 & .010 \\
\hline & SERVICE QUALITY & .747 & .160 & .592 & 4.672 & .000 \\
\hline
\end{tabular}


The bivariate relationships between the variable combinations can be visualized from the scatterplot matrix displayed in Figure 2. Each scatter plot in the matrix visualizes the relationship between a pair of variables, allowing many relationships to be explored in one chart. As seen from the matrix, the data points in the scatterplot for service quality against tourist attitude, destination competitiveness and medical tourist participation are tightly clustered along the imaginary line. The correlation statistics revealed that service quality correlated significantly with tourist attitude (42.8\%), destination competitiveness (62.6\%) and tourist participation (37.6\%). These show that as service quality increases, the tourist attitude towards outbound medical tourism becomes more positive, the tourist perception of destination competiveness increases and ultimately, they are more likely to participate in outbound medical tourism.

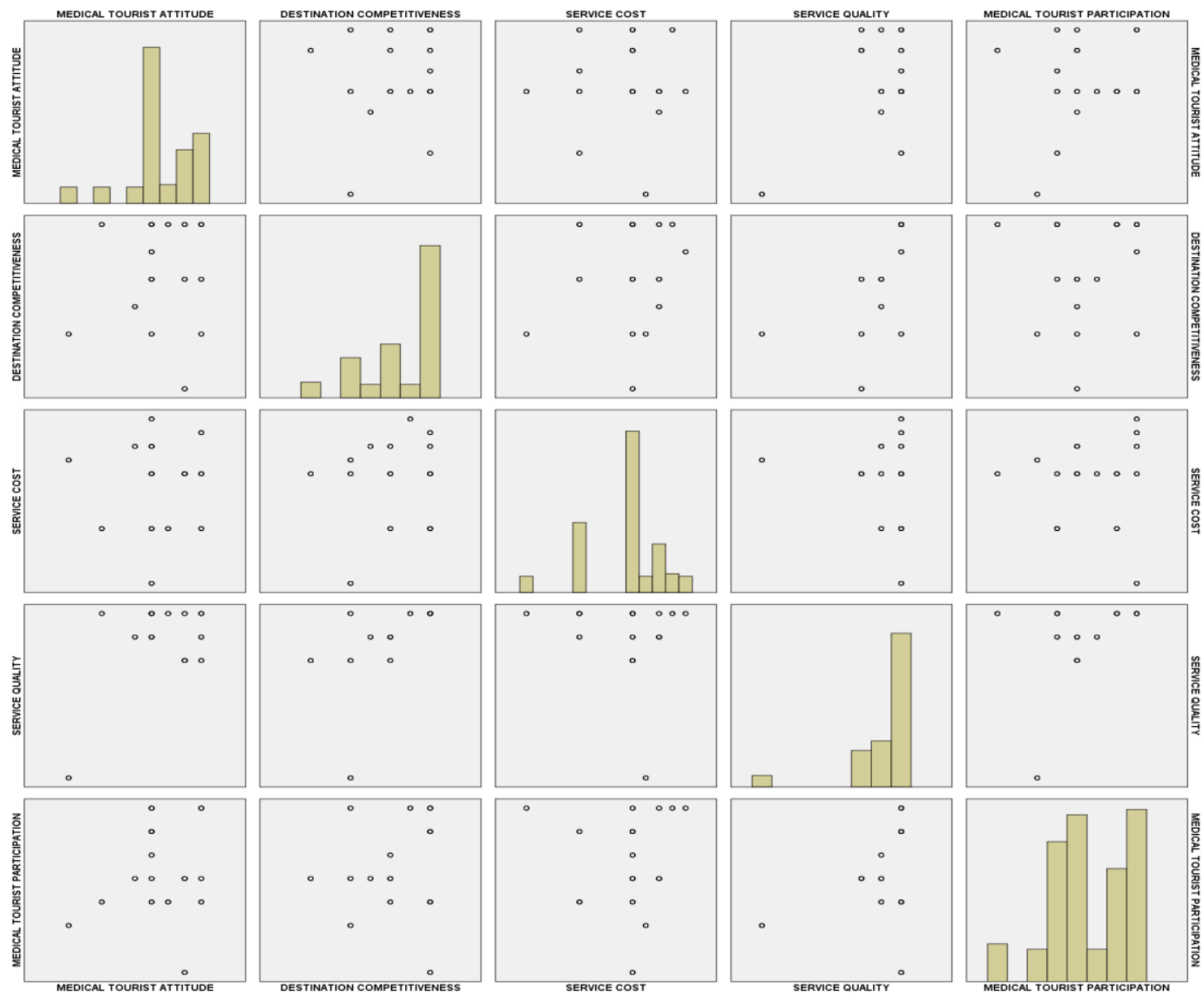

Figure 2. Scatterplot Matrix (SPLOM) Chart showing correlations among variables

From the result of the analysis, we accept the first null hypothesis and reject the second, third and fourth null hypotheses. The results are summarized as follows:

1. Tourist attitude has no significant influence on outbound medical tourism participation.

2. Medical destination competitiveness significantly influences outbound medical tourism negatively.

3. Medical service cost significantly influence outbound medical tourism positively.

4. Medical service quality significantly influences outbound medical tourism positively.

The result of the first hypothesis reveals that medical tourist attitude has no significant influence on outbound medical tourism. The finding is in harmony with that of Sultana et al. (2014) whose study though carried out in India revealed that tourist attitude is less important in comparison with other factors (service quality, cost and destination competitiveness) affecting their destination choice. This proves that universally, tourist attitude plays little or no role in an individual's participation in outbound medical tourism. This is likely due to the fact that medical tourism is very different from the general tourism as it is backed by a strong reason- health concern of the tourist. Hence, an attitude such as willingness to show off social status is inconsequential in medical tourism. This finding is true because medical tourists actually engage in medical tourism as a result of recommendation from health service providers. Their main reason for visiting medical destination is to obtain treatment which is a necessity; hence their attitude has an insignificant effect on their propensity to participate in medical tourism. From the test of hypothesis two it is seen that medical destination competitiveness significantly influences outbound medical tourism negatively. This result is backed by the research finding of Lajevardi (2016) whose study showed that medical tourists' perceptions are based on motivational factors, destination image, quality, value, and satisfaction which occurred after the medical trips. His work further revealed that destination image had the strongest impact on perceived quality. When a medical tourist perceives that the destination is very competitive in terms of its tourist appeal and attractiveness, he or she will be more willing to participate in medical tourism. Hence, destination competitiveness affects participation in outbound medical tourism.

Hypothesis three reveals that medical service cost significantly influences outbound medical tourism positively. This finding is at par with that of Kim et al. (2019) who analyzed the factors that determine the motivation and behavior of potential medical tourists on destination choice, with particular emphasis on the role played by destination image in the case of Thailand. Individuals who are more inclined to undertake medical tourism are those who consider the cost of health-care services in their home countries to be financially unaffordable (Ushakov et al., 2019). It thus can be gleaned that medical cost encourages participation in outbound medical tourism. However, in the Nigerian situation, medical tourists do not consider the cost of treatment to be unaffordable. They rather consider the cost of treatment abroad to be commensurate with the quality of treatment received. Finally, the result of the hypothesis test showed that medical service quality significantly influences outbound medical tourism positively. Again, this finding is in agreement with that of Jotikasthira 
(2010) who noted that prospective medical tourists are particularly motivated to consider four destination attributes in choosing a medicaltourism destination- saving potential; quality of care; hygiene issues. To further buttress this finding, the study by Sultana et al. (2014) revealed that in Indian context, medical tourists consider service quality and cost mostly in selecting any medical destination.

\section{CONCLUSION}

This study concludes that medical tourists are propelled to engage in medical tourism by certain demand factors which include medical cost, medical service quality and destination competitiveness. These factors will continue to appeal to tourist who can obtain them abroad. In other words, any country or destination offering medical tourism appealing features such as low cost, high service quality and attractive sites will keep reaping the dividends of medical tourism. The reverse is the case for countries that do not take these factors to be of utmost importance in their medical system.

In line with the research findings of this paper, the following recommendations are proffered:

1. The competitiveness of Nigeria as a medical destination could be enhanced by the acquisition of state-of-the art medical facilities which would appeal to patients and aid the recuperation process.

2. The cost of treatment in Nigerian hospitals should be commensurate with the quality of treatment received. Patient should feel that they get value for their money. This can be achieved by adding ancillary services such as an exercise routine for patients.

3. The quality of medical services in Nigeria should be beefed up. Care givers should provide personalized attention to individual patient. When sincere personal interest in patients is displayed, there would be less reason to travel out for minor treatments.

4. Since medical tourism industry has been acknowledged to be a lucrative sector resulting in huge amount being spent for treatment outside the shores of the nation, it is necessary to reduce this trend. This paper has x-rayed some of the determinants responsible for this trend.

\section{REFERENCES}

Abubakar, M., Basiru, S., Oluyemi, J., Abdulateef, R., Atolagbe, E., Adejoke, J. \& Kadiri, K. (2018). Medical Tourism in Nigeria: Challenges and Remedies to Health Care System Development. International Journal of Development and Management Review, 13(1), 223-238.

Al-Amin, M., Makarem, S.C., \& Pradhan. R. (2011). Hospital ability to attract international patients: a conceptual framework. International Journal of Pharmaceutical Health Market, 5(3), 205-221. https://doi.org/10.1108/17506121111172211

Arsil, P., Li, E. \& Bruwer, J. (2016). Using means-end chain analysis to reveal consumers' motivation for buying local foods: An exploratory study. Gadjah Mada International Journal of Business, 18(3), 285-300. https://doi.org/10.22146/gamaijb.16900

Calderwood, L.U., \& Soshkin, M. (2019). The travel \& tourism competitiveness report 2019: Travel and tourism at a tipping point. World Economic Forum, Geneva, Switzerland, pp. 1-63.

Carvache-Franco, M., Segarra-Oña, M., \& Carrascosa-López, C. (2019). Motivations analysis in ecotourism through an empirical application: Segmentation, characteristics and motivations of the consumer. GeoJournal of Tourism and Geosites, 24(1), 60-73. https://doi.org/10.30892/gtg.24106-343

Crooks, V.A., Turner, L., Snyder, J., Johnston, R. \& Kingsbury, P. (2011). Promoting medical tourism to India: Messages, images, and the marketing of international patient travel. Social Science Medicine, 72(5), 726-732. https://doi.org/10.1016/j.socscimed.2010.12.022

Datta, B. (2020). Factors affecting the satisfaction level of medical tourists: a case study of Delhi national capital region. GeoJournal of Tourism and Geosites, 29(2), 628-635. https://doi.org/10.30892/gtg.29219-494

Fetscherin, M., \& Stephano, R.M. (2016). The medical tourism index: Scale development and validation. Tourism Management, 52, 539-556. https://doi.org/10.1016/j.tourman.2015.08.010

Haarhoff, R. \& Mokoena, L.G. (2017). The market place of medical tourism facilitators in South Africa. African Journal of Hospitality, Tourism and Leisure, 6(3), 1-17.

Hosseini, H. (2010). Strategies to contain the high and rising costs of health: Will they increase existing health care disparities and are they ethical? Humanomics, 26(2), 112-123. https://doi.org/10.1108/08288661011074918

Ile, F.L. \& Țigu, G. (2017). Medical tourism market trends - an exploratory research. Proceedings of the 11th International Conference on Business Excellence held at Bucharest, Romania, 1111-1121. https://doi.org/10.1515/picbe-2017-0114

Jeng, M. \& Yeh, T. (2016). The effect of consumer values on the brand position of green restaurants by means-end chain and laddering interviews. Service Business, 10, 223-238. https://doi.org/10.1007/s11628-015-0266-1

Jiang, S., Scott, N. \& Ding, P. (2018). Motivations of experienced leisure travellers: A means-end chain study on the Chinese outbound market. Journal of Vacation Marketing, 25(2), 225-238. https://doi.org/10.1177/1356766718763694

Jing, W., Xiang, Y. \& Lei, M. (2017). The deeper the love, the deeper the hate. Frontiers in Psychology, 8, 19-40. https://doi.org/10.3389/fpsyg.2017.01940

Jotikasthira, N. (2010). Salient factors influencing medical tourism destination choice. DBA thesis, Southern Cross University, Lismore, NSW.

Kapoor, R. (2017). Viewing life of senior citizen convicts in Tihar from the lens of gerontological theories. Sociology and Criminology, 5(2), 1-5. https://doi.org/10.4172/2375-4435.1000170

Kim, S., Arcodia, C., \& Kim, I. (2019). Critical success factors of medical tourism: The case of South Korea. International Journal of Environmental Research and Public Health, 16(24), 2-15. https://doi.org/10.3390/ijerph16244964

Kiper, T. (2013). Advances in Landscape Architecture (ebook). Intechopen. https://doi.org/10.5772/55749

Kuranchie-Mensah, E. B. \& Amponsah-Tawiah, K. (2016). Employee motivation and work performance: A comparative study of mining companies in Ghana. Journal of Industrial Engineering and Management (JIEM), 9(2), 255-309. http://dx.doi.org/10.3926/jiem.1530

Lajevardi, M. (2016). A comprehensive perspective on medical tourism context and create a conceptual framework. Journal of Tourism, Hospitality and Sports, 20, 7-25. https://doi.org/10.4172/2167-0269.1000236

Lin, C., Jeng, M. \& Yeh, T. (2018). The elderly perceived meanings and values of virtual reality leisure activities: A means-end chain approach. International Journal of Environmental Research and Public Health, 15(4), 663. https://doi.org/10.3390/ijerph15040663

Makinde, O.A. (2016). Physicians as medical tourism facilitators in Nigeria: Ethical issues of the practice. Croatian Medical Journal, 57(6), 601-604. https://doi.org/10.3325/cmj.2016.57.601

Murayama, K. (2018). The science of motivation: Multidisciplinary approaches advance research on the nature and effects of motivation. Psychological Science Agenda, 32(6), 1-10.

Pakurár, M., Haddad, H., Nagy, J., Popp, J. \& Oláh, J. (2019). The service quality dimensions that affect customer satisfaction in the Jordanian banking sector. Sustainability, 11(1113), 1-24, https://doi.org/10.3390/su11041113

Roy, D., Dhir, G.M., \& Ahsan, M.K. (2017). Factors affecting tourist satisfaction: A study in Sylhet region. ABC Research Alert, 4(3), 9-20. https://doi.org/10.18034/abcra.v4i3.307

Setiawan, A. (2018). Needs hierarchy in T. B. Silalahi's Novel Toba dreams. Knowledge E Social Sciences, 106-115. https://doi.10.18502/kss.v3i4.1923

Smith, M. \& Puczko, L. (2014). Health, Tourism and Hospitality. Spas, Wellness and Medical Travel. Routledge, London and New York, pp. 1-224.

Sultana, S., Haque, A., Momen, A. \& Yasmin, F. (2014). Factors affecting the attractiveness of medical tourism destination: an empirical study on IndiaReview article. Iranian Journal of Public Health, 43(7), 867-876.

Ushakov, D.S., Yushkevych, O.O., Ovander, N.L., Tkachuk, H.Y., \& Vyhovskyi, V.H. (2019). The strategy of Thai medical services promotion at foreign markets and development of medical tourism. GeoJournal of Tourism and Geosites, 27(4), 1429-1438. https://doi.org/10.30892/gtg.27426-445 